\title{
PERBANDINGAN DAMPAK EL NINO KUAT 2015/16 DAN 1997/98 TERHADAP CURAH HUJAN DI PROVINSI BALI - INDONESIA
}

\section{COMPARISON OF THE IMPACT OF 2015/16 AND 1997/98 STRONG EL NINO ON RAINFALL IN BALI PROVINCE - INDONESIA}

\author{
I Wayan Andi Yuda ${ }^{1,2 *}$, Rakhmat Prasetia ${ }^{1}$, Nursa'idah ${ }^{1}$ dan Made Dwi Wiratmaja ${ }^{1}$ \\ ${ }^{1}$ Badan Meteorologi Klimatologi dan Geofisika Stasiun Klimatologi Jembrana \\ ${ }^{2}$ Program Pascasarjana Ilmu lingkungan Universitas Udayana \\ *E-mail: andiyudaiwayan@gmail.com
}

Naskah masuk: 26 Januari 2020, Naskah diperbaiki:18 Juni 2020, Naskah diterima: 23 Juni 2020

\section{ABSTRAK}

Penelitian ini bertujuan untuk mengetahui perbandingan fenomena El Nino 2015/16 dan 1997/98 dari segi indeks dan dampak keduanya terhadap curah hujan di Provinsi Bali - Indonesia. Metode analisis yang digunakan berupa metode Korelasi Pearson dan statistik deskriptif terhadap data Indeks Nino 3.4 yang dikonversi menjadi Oceanic Nino Index (ONI) dan data curah hujan bulanan di 22 titik penakar hujan Provinsi Bali. Hasil penelitian menunjukan El Nino 2015/16 (indeks tertinggi 2.37) sedikit lebih kuat daripada El Nino 1997/98 (indeks tertinggi 2.33). Berdasarkan siklus hidupnya, El Nino 2015/16 lebih lama bertahan dibandingkan dengan El Nino 1997/98. Hubungan antara El Nino dengan curah hujan Bali diketahui lebih kuat pada periode September-Oktober-Nopember (SON) dibandingkan dengan periode DesemberJanuari-Februari (DJF). Kemudian setelah dilakukan perbandingan antara kedua kejadian El Nino Kuat tersebut, ternyata dampak penurunan curah hujan di Provinsi Bali saat EI Nino Kuat 2015/16 (-6\% s/d $-46 \%)$ tidak separah dampak penurunan curah hujan saat fenomena El Nino Kuat 1997/98 (-18\% s/d $72 \%)$.

Kata kunci: El Nino, Oceanic Nino Index, Curah hujan

\section{ABSTRAK}

This study aims to determine the comparison of the 2015/16 and 1997/98 El Nino phenomena in terms of the index and their impact on rainfall in Bali Province - Indonesia. The analytical method used is the Pearson Correlation method and descriptive statistics on the Nino 3.4 index data which is converted to Oceanic Nino Index (ONI) and monthly rainfall data at 22 rain gauges in Bali Province. The results showed the 2015/16 El Nino (highest index 2.37) was slightly stronger than El Nino 1997/98 (the highest index 2.33). Based on its life cycle, EI Nino 2015/16 lasts longer than El Nino 1997/98. The relationship between EI Nino and Bali rainfall is stronger in the September-OctoberNovember (SON) period compared to the December-January-February (DJF) period. Then after a comparison between the two strong El Nino events, it turns out that the impact of decreasing rainfall in Bali Province during Strong El Nino 2015/16 (-6\% to -46\%) was not as severe as the impact of decreasing rainfall during the 1997/98 El Niño phenomenon. (-18\% to $-72 \%)$.

Keywords: El Nino, Oceanic Nino Index, Rainfall 


\section{Pendahuluan}

El Nino merupakan salah satu fenomena anomali laut yang diketahui sangat berpengaruh terhadap iklim global. Istilah El Nino awalnya digunakan oleh nelayan pantai barat Peru untuk menyatakan kemunculan fenomena tahunan berupa arus hangat laut yang bergerak ke arah selatan sepanjang pantai barat Peru pada periode Natal. Saat ini, istilah tersebut digunakan untuk menyatakan fenomena pemanasan laut yang terjadi di Samudera Pasifik Ekuator dengan interval kejadian sekitar 4 tahun sekali (dengan batas 2 hingga 7 tahun) [1]. Dampak El Nino terhadap curah hujan dan suhu telah banyak dianalisis dalam banyak studi ilmiah [2,3]. Di daerah tropis, kondisi lebih kering dan lebih hangat saat El Nino terjadi di Benua Amerika Selatan bagian utara dan timur laut, Asia Tenggara, Australia bagian utara, India bagian tengah dan utara, dan barat daya Benua Afrika. Sebaliknya, fenomena El Nino menyebabkan peningkatan curah hujan di beberapa wilayah seperti Benua Amerika Selatan bagian selatan, Benua Afrika ekuatorial bagian barat, India bagian selatan dan China bagian selatan [4].

Kejadian El Nino terkuat yang pernah tercatat adalah El Nino 1997/98 dengan nilai indeks tertinggi sejak 64 tahun sebelumnya. Oleh sebab itu El Nino 1997/98 dinyatakan juga sebagai 'climate event of the century' [5]. Dampak dari fenomena El Nino 1997/98 secara global dirasakan diantaranya dalam bentuk musim kemarau panjang di Indonesia dan wilayah Amazon hingga memicu kebakaran hutan. Musim kemarau yang berkepanjangan pada periode tersebut dicirikan dengan rendahnya tutupan awan, curah hujan dan penguapan. Sebaliknya peningkatan aktivitas konveksi dan peningkatan curah hujan terjadi sepanjang Pasifik Tropis bagian timur hingga wilayah Peru yang memicu banjir, tanah longsor, dan curah hujan ekstrim [6].

Beranjak dari tahun 1997/98, fenomena EI Nino Kuat ternyata kembali terjadi pada tahun 2015/16. Menurut laporan organisasi World Food Programme (WFP) pada Maret 2016, Fenomena El Nino yang mulai terjadi pada awal tahun 2015 ini merupakan salah satu El Nino terkuat yang pernah terjadi dan berdampak pada ketersediaan pangan dunia. Di Indonesia sendiri, El Niño 2015 menyebabkan curah hujan yang lebih rendah khususnya wilayah timur dan berdampak pada rendahnya tingkat penanaman padi hingga $80 \%$ lebih rendah dari normalnya [7].
Dari kedua fenomena El Nino terkuat pada masanya (1997/98 dan 2015/16), ada kemungkinan terdapat persamaan dan perbedaan antara kedua EI Nino Kuat tersebut sehingga menarik untuk membandingkan fase pertumbuhan, puncak, dan meluruh dari keduanya.Perbandingan perkembangan fenomena tersebut dapat dimonitor dengan memperhatikan Oceanic Nino Index (ONI). Menurut National Oceanic and Atmospheric Administration (NOAA) Amerika [8], Indeks tersebut didefinisikan sebagai rata-rata tiga bulan dari anomali suhu permukaan laut (SPL) dari normalnya untuk wilayah Pasifik khatulistiwa (wilayah Nino3.4; $120{ }^{\circ} \mathrm{BB}-170$ $\left.{ }^{\circ} \mathrm{BB}, 5{ }^{\circ} \mathrm{LU}-5^{\circ} \mathrm{LS}\right)$. Nilai ONI lebih besar atau sama dengan +0.5 mengindikasikan fenomena El Nino. Sedangkan nilai ONI lebih kecil atau sama dengan -0.5 mengindikasikan kondisi La Nina.

Selain diskusi mengenai kedua fenomena El Nino (1997/98 dan 2015/16) itu sendiri, pembahasan mengenai perbandingan dampak yang ditimbulkan oleh keduanya terhadap curah hujan di salah satu wilayah Indonesia juga akan disajikan dalam tulisan ini. Menarik untuk mengetahui apakah kedua fenomena ini memiliki dampak yang sama atau berbeda. Pengetahuan tentang dampak yang ditimbulkan oleh fenomena El Nino Kuat sangat penting untuk diketahui sebagai bahan antisipasi jika fenomena ini kembali terjadi pada waktu yang akan datang.

Wilayah penelitian yang dipilih dalam paper ini adalah wilayah Provinsi Bali yang terletak pada $8^{\circ} 3^{\prime} 40^{\prime \prime}$ LS - 8 50 '48" LS dan $114^{\circ} 25^{\prime} 53^{\prime \prime B T}$ $115^{\circ} 42^{\prime} 40^{\prime \prime}$ BT. Dari posisi geografis, Provinsi Bali masuk dalam zona angin monsoon dan memiliki pola hujan monsoon. Pemilihan lokasi dengan pola hujan monsun ini penting mengingat pengaruh El Nino berbeda pada setiap daerah dengan pola hujan yang berbeda. Menurut Aldrian dan Susanto[9], daerah dengan pola hujan monsun pengaruh fenomena iklim ini kuat. Hal tersebut didukung oleh penelitian Yuda dan Prasetia [10] yang menunjukkan secara umum fenomena El Nino konsisten mengakibatkan penurunan anomali curah hujan di beberapa titik pos hujan provinsi Bali pada bulan Januari dan September. Dengan demikian, Provinsi Bali dapat dinyatakan sebagai wilayah terdampak EI Nino. Tulisan ini diharapkan dapat menggambarkan fenomena El Nino 2015/16 dan El Nino 1997/98 serta perbandingan dampak keduanya terhadap curah hujan di Provinsi Bali. 


\section{Metode Penelitian}

Penelitian ini menggunakan dua jenis data yaitu data curah hujan dan data anomali suhu permukaan laut. Data curah hujan bulanan didapatkan dari Stasiun Klimatologi Jembrana Bali periode 1981-2016 di 22 lokasi penakar hujan di Provinsi Bali (Gambar 1). Selanjutnya data anomali suhu permukaan laut bulanan (normal 1981-2010) di wilayah Nino $3.4\left(5^{\circ} \mathrm{LU}-\right.$ $5^{\circ}$ LS dan $\left.170-120^{\circ} \mathrm{BB}\right)$ periode $1981-2016$ diunduh dari website Climate Prediction Center (CPC) [11].Data tersebut selanjutnya disebut Indeks Nino 3.4 .

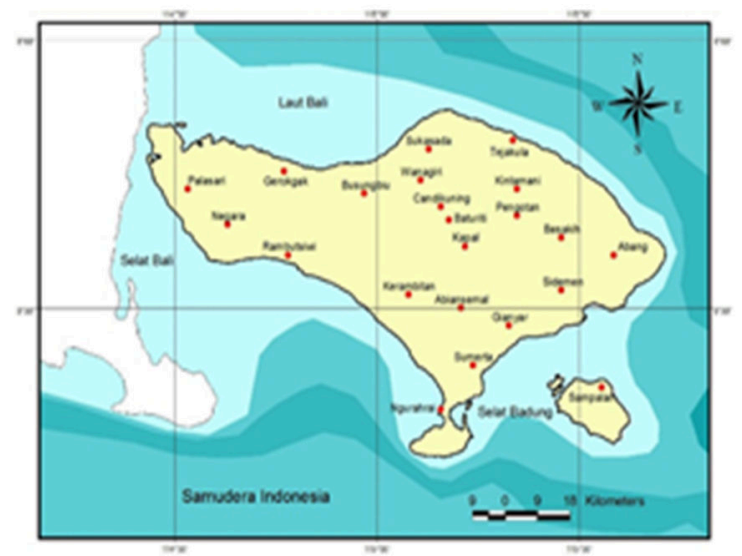

Gambar 1. Lokasi Penakar Hujan di Provinsi Bali

Pengolahan dan analisis data dalam penelitian ini dilakukan dengan tahapan sebagai berikut:

a. Pembuatan grafik indeks Nino 3.4 bulan Januari 1997 s/d Agustus 1998 dan Januari 2015 s/d Agustus 2016 beserta moving average-nya. Moving average 3 bulanan Indeks Nino 3.4 disebut dengan Oceanic Nino Index (ONI). Menurut National Oceanic atelnet 172.25.0.35 9881 -f D:IFTPIdataozonIRealDatalozon_30-082020 0133.csv

b. nd Atmospheric Administration (NOAA) Amerika [12] dalam situsnya dituliskan bahwa awal kejadian El Nino ditentukan jika nilai ONI mencapai atau melebihi 0.5 dan kemudian bertahan minimal 5 periode 3 bulanan berturut-turut. Rumus moving average:

$$
M A_{3 \text { bulan }}=\frac{\sum_{i=1}^{3} D_{i}}{3}
$$

Keterangan: MA3bulan adalah Nilai moving average dari Indeks Nino 3.4 pada periode 3 bulan tertentu (ONI) dan $\mathrm{Di}$ adalah nilai Indeks Nino 3.4 pada bulan $i$.

Selanjutnya dilakukan analisis terhadap grafik Nino 3.4 dan ONI untuk mengetahui perbandingan awal, puncak, dan berakhirnya masing-masing El Nino. Dalam pembahasan, periode 3 bulanan disingkat menjadi 3 huruf depan dari nama bulan berurutan yang dirata-ratakan.

c. Perhitungan koefisien korelasi ONI dengan rata-rata curah hujan Bali periode September Oktober Nopember (SON) dan Desember Januari Februari (DJF). Pemilihan periode SON dan DJF berdasarkan kondisi El Nino 1997/98 dan 2015/16 yang masuk kategori kuat (ONI $>1.5$ ) pada periode tersebut. Perhitungan koefisien korelasi dilakukan untuk mengetahui hubungan linear antara EI Nino dan curah hujan di Provinsi Bali.Rumus Korelasi Pearson[13]:

$$
r_{x y}=\frac{n\left(\sum x y\right)-\left(\sum x\right)\left(\sum y\right)}{\sqrt{\left[n \sum x^{2}-\left(\sum x\right)^{2}\right]\left[n \sum y^{2}-\left(\sum y\right)^{2}\right]}}
$$

Dengan $r$ adalah koefisien korelasi antara $x$ dan $y$. Nilai ONI diwakili oleh $x$ sedangkan $y$ adalah rata-rata 3 bulanan curah hujan observasi pada periode yang sama, dan $n$ adalah banyaknya tahun yang digunakan dari 1997 hingga 2016.

d. Perhitungan persentase anomali curah hujan setiap titik pengamatan terhadap normalnya (rata-rata 1981-2010) pada periode SON-DJF 1997/98 dan 2015/16 untuk mengetahui penurunan atau peningkatan curah hujan Bali pada periode El Nino Kuat tersebut.

e. Dilakukan perhitungan perbedaan curah hujan Provinsi Bali masing-masing bulan pada periode SONDJF tahun 1997/1998 dan 2015/2016. Perbedaan dihitung dengan mengurangi curah hujan pada suatu bulan di tahun 2015/2016 dengan curah hujan pada bulan yang sama di tahun 1997/1998. Nilai positif (+) menunjukan curah hujan tahun 2015/2016 pada bulan yang dibandingkan lebih tinggi daripada tahun 1997/1998 sedangkan nilai negatif menunjukan kondisi yang sebaliknya.

\section{Hasil dan Pembahasan}

Analisis El Nino 1997/98 dan 2015/16 berdasarkan Index Nino 3.4. Berdasarkan Gambar 2 terlihat bahwa El Nino 1997/98 dimulai pada periode AMJ sedangkan EI Nino 2015/16 dimulai pada periode FMA atau lebih cepat 2 bulan dari El Nino 1997/98. El Nino 1997/98 mencapai kategori kuat (ONI >1.5) pada periode JAS dan bertahan hingga JFM. Sedangkan El Nino 2015/16 mencapai kategori kuat pada periode ASO hingga FMA. El Nino 
2015/16 mencapai kategori kuat satu bulan lebih lambat dari El Nino 1997/98. Pola Indeks Nino 3.4 pada kedua kejadian El Nino tersebut mulai terlihat mirip pada bulan Juni hingga April dengan puncak indeks terkuat pada bulan November.

Jika dibandingkan dari segi Indeks Nino 3.4 maka El Nino 2015/16 (indeks tertinggi 2.37) sedikit lebih kuat daripada El Nino 1997/98 (indeks tertinggi 2.33). Bulan Nopember s/d Maret merupakan periode indeks Nino 3.4 tahun 2015/16 lebih kuat daripada Indeks Nino tahun 1997/98. Selanjutnya, berdasarkan waktu bertahannya, maka El Nino 2015/16 lebih lama dibandingkan dengan El Nino 1997/98. Kedua fenomena El Nino tersebut meluruh pada periode yang sama yaitu AMJ

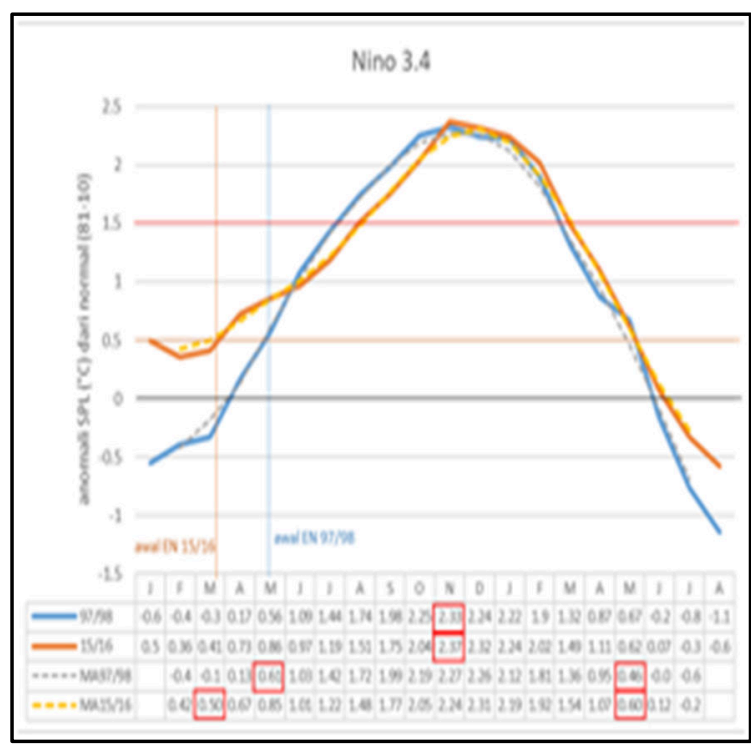

Gambar 2. Grafik Indeks Nino 3.4 tahun 1997/1998 dan 2015/2016.
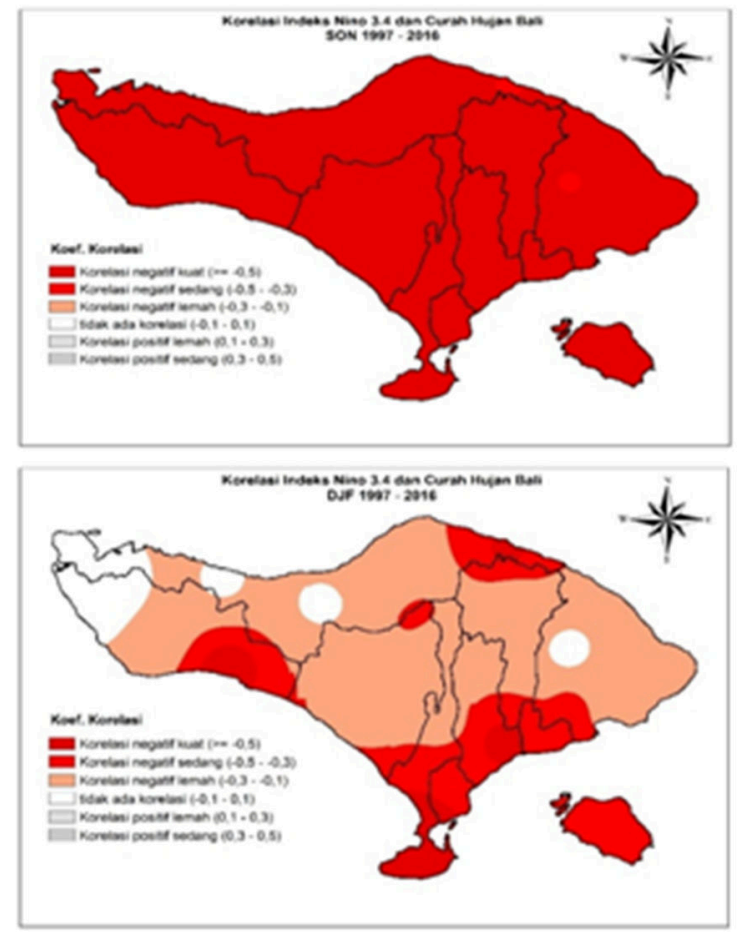

Gambar 3. Peta Korelasi antara Oceanic Nino Index (ONI) dan Curah hujan Bali periode SON (atas) dan DJF (bawah) periode 1997-2016

Hubungan Oceanic Nino Index (ONI) dan Curah Hujan Provinsi Bali. Nilai koefisien korelasi antara data ONI dan curah hujan untuk periode SON ditunjukan oleh Gambar 3 (atas) berkisar antara -0.5 hingga -0.8 . Hal ini menunjukan hubungan linear negatif yg dominan kuat antara perubahan suhu permukaan laut di Pasifik Tengah dan curah hujan di Provinsi Bali. Sedangkan nilai koefisien korelasi antara data ONI dan curah hujan untuk periode DJF yang ditunjukan oleh Gambar 3 (bawah) berkisar antara 0 hingga 0.8 . Nilai koefisien korelasi dominan berkisar antara 0 hingga -0.3 menunjukan hubungan linear negatif lemah antara ONI dan curah hujan di sebagian besar wilayah Bali pada periode DJF. Wilayah yang curah hujannya memiliki hubungan linear cukup kuat dengan ONI pada periode ini hanya terdapat di sebagian kecil Bali bagian selatan dan Bali bagian utara.

Berdasarkan analisis nilai koefisien korelasi yang ditampilkan dalam kedua gambar tersebut dapat diketahui bahwa El Nino yg direpresentasikan oleh ONI secara statistik berhubungan dengan curah hujan di Provinsi Bali dan secara lebih khusus dapat dinyatakan berasosiasi dengan kondisi pengurangan curah hujan di wilayah ini. Pengaruh El Nino terhadap curah hujan Provinsi Bali lebih dominan pada periode SON dibandingkan pada periode DJF. Hal ini bersesuaian dengan penelitian 
terdahulu [14,15] yang menyatakan curah hujan di Indonesia sangat dipengaruhi oleh ENSO pada musim kemarau (Juni-November) dan lemah dipengaruhi pada musim hujan (Desember-Mei). Menurut Aldrian [16],hal ini disebabkan karena pengaruh datangnya angin Baratan (angin Monsoon Asia) pada periode DJF yang membawa massa udara basah ke sebagian besar wilayah Indonesia.

\section{Perbandingan Anomali Curah Hujan Musiman pada saat EI Nino 1997/98 dengan 2015/16. Berdasarkan Gambar 4 dapat diketahui bahwa kondisi curah hujan musiman (September-Februari) lebih rendah dari normalnya (anomali negatif) terjadi di sebagian besar wilayah Provinsi Bali saat El Nino Kuat 1997/98 maupun saat El Nino Kuat 2015/16. Kondisi anomali negatif curah hujan saat EI Nino Kuat 1997/98 (Gambar 4 atas) terlihat merata di seluruh wilayah Bali dengan persentase berkurangnya curah hujan terhadap normalnya berkisar antara $-18 \%$ s/d $-72 \%$. Intensitas pengurangan curah hujan lebih dari $600 \mathrm{~mm} / \mathrm{enam}$ bulan terjadi di wilayah Bali bagian tengah dan bagian selatan. Sedangkan kondisi anomali negatif curah hujan saat EI Nino Kuat 2015/16 (Gambar 4 bawah) terlihat tidak menyeluruh dengan kisaran persentase berkurangnya curah hujan terhadap normalnya berkisar antara $-6 \% \quad \mathrm{~s} / \mathrm{d} \quad-46 \%$. Intensitas pengurangan curah hujan lebih dari 600 $\mathrm{mm} / \mathrm{enam}$ bulan hanya terjadi di sebagian kecil Bali bagian tengah dan bagian timur. Bahkan terdapat wilayah Bali bagian utara dan barat yang mengalami anomali curah hujan positif atau penambahan curah hujan dengan persentase hingga $26 \%$.}

Berdasarkan analisis terhadap kedua peta anomali tersebut maka dapat diketahui bahwa curah hujan selama periode SeptemberFebruari di Provinsi Bali saat El Nino 1997/98 lebih rendah dibandingkan curah hujan saat El Nino 2015/16. Berkurangnya curah hujan pada periode September 1997 hingga Februari 1998 terjadi menyeluruh di wilayah Bali. Sedangkan saat El Nino 2015/2016, disamping terjadi pengurangan curah hujan ternyata juga terjadi penambahan curah hujan di wilayah Bali bagian utara. Hal ini menunjukan dampak El Nino 1997/98 lebih tegas dibandingkan dampak El Nino 2015/16 terhadap kondisi curah hujan di Provinsi Bali.

Pengaruh El Nino 2015/16 terhadap curah hujan di Provinsi Bali lebih lemah dibandingkan dengan pengaruh El Nino 1997/98 padahal kedua El nino tersebut berkategori kuat. Berdasarkan penelitian sebelumnya[17,18], meskipun kedua El Nino tersebut sama-sama kuat secara indeks namun keduanya sangat berbeda dari segi dinamika atmosfer-laut yang mendasari. Mereka menemukan bahwa fenomena El Nino 1997/98 berevolusi dengan didominasi oleh dinamika klasik EI Nino Pasifik Timur (East Pacific El Nino - EP EI Nino) sedangkan evolusi El Nino 2015/16 menunjukan fenomena campuran antara dinamika El Nino Pasifik Timur dan El Nino Pasifik Tengah (Central Pasifik El Nino - CP El Nino). Pengaruh yang kuat dari dinamika CP EI Nino menyebabkan kondisi 2015/16 menyimpang dari fenomena 1997/98 terutama pada fase peluruhan (Desember-Maret). Perbedaan dampak ini juga mengakibatkan curah hujan ekstrim di Amerika Serikat tahun 2015/16 tidak separah tahun 1997/98. Khasus ini menunjukan bahwa dampak dari El Nino terhadap curah hujan tidak bisa dilihat langsung dari tinggi rendahnya indeks EI Nino itu sendiri namun perlu diperhatikan evolusi dinamika atmosfer-laut yang mendasari suatu Fenomena El Nino Kuat.
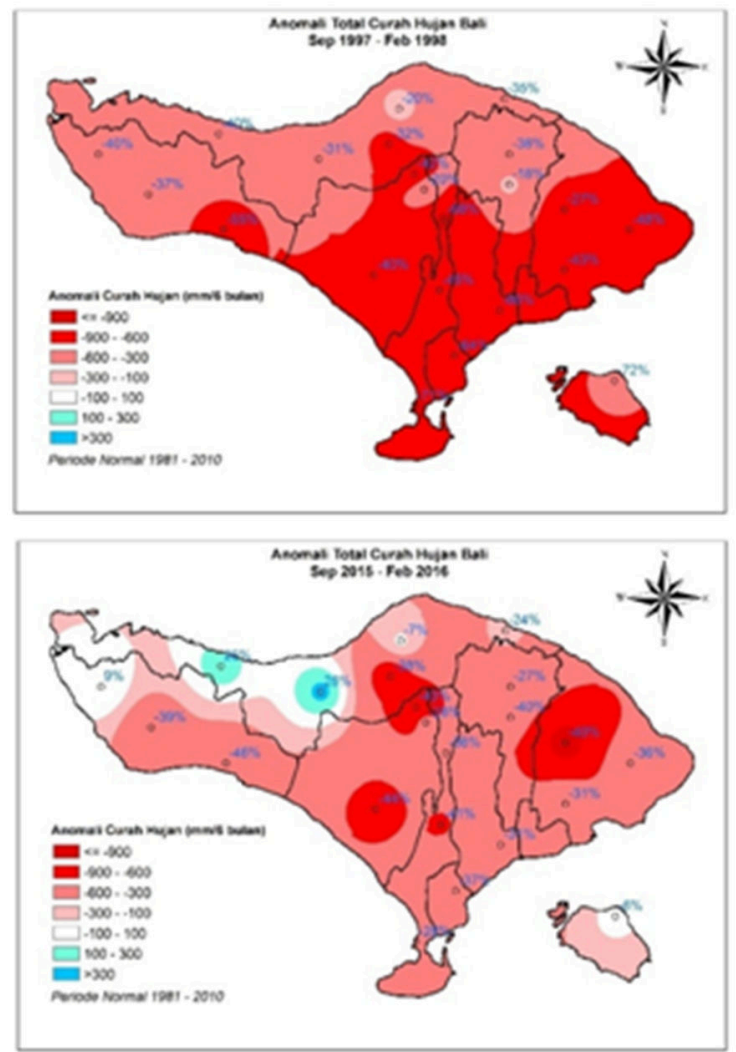

Gambar 4. Anomali total curah hujan musiman Provinsi Bali periode September 1997 s/d Februari 1998 (atas) dan periode September $2015 \mathrm{~s} / \mathrm{d}$ Februari 2016 (bawah) dibandingkan kondisi normal 30 tahun $(1981-2010)$ 
Perbandingan Curah Hujan Bulanan saat EI Nino 1997/98 dan 2015/16. Untuk melihat perbedaan kondisi curah hujan secara lebih mendetail maka dilakukan perbandingan curah hujan antara bulan yang sama untuk tahun 1997/98 dan 2015/16. Hasil perhitungan selisih curah hujan bulanan 1997/98 dan 2015/16 selama periode EI Nino Kuat ditampilkan dalam Gambar 5 dan 6. Kondisi curah hujan pada bulan September-Oktober pada tahun 1997 dan 2015 cenderung sama. Hal ini ditunjukan dengan kisaran selisih antara $-100 \mathrm{~s} / \mathrm{d}+100$ $\mathrm{mm} /$ bulan yang dapat dilihat pada Gambar $5 a$ dan 5b. Pada bulan November, kondisi curah hujan juga masih relatif sama antara tahun 2015 dan 1997(gambar 5c). Terdapat variasi curah hujan November tahun 2015 lebih rendah dibandingkan tahun 1997 dengan kisaran selisih $-200 \mathrm{~mm}$ s/d $-400 \mathrm{~mm}$ di wilayah Bali bagian timur saat puncak El Nino pada bulan November (puncak indeks Nino 3.4 lihat gambar 2).
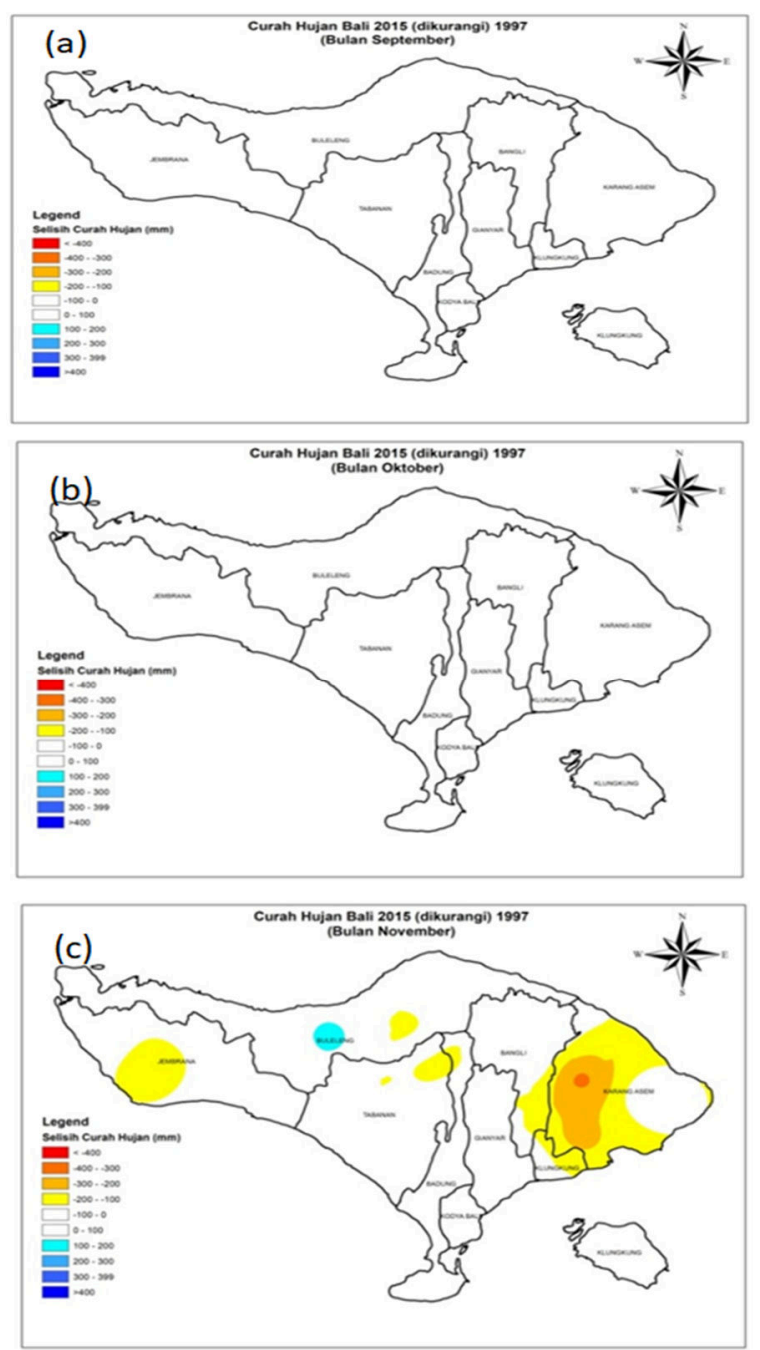

Gambar 5. Perbedaan Curah Hujan Bulanan tahun 2015 (dikurangi) 1997 untuk bulan (a) September, (b) Oktober, dan (c) Nopember
Selanjutnya pada bulan Desember, kondisi curah hujan tahun 2015 secara umum lebih tinggi dibandingkan tahun 1997 dengan kisaran selisih $+100 \mathrm{~mm}$ s/d $+300 \mathrm{~mm}$ untuk sebagian besar wilayah Bali (Gambar 6a). Sedangkan kondisi curah hujan Desember 2015 lebih rendah daripada 1997 terdapat di bagian kecil Bali bagian utara.

Berdasarkan Gambar 6b kondisi curah hujan bulan Januari tahun 2016 lebih tinggi dibandingkan bulan yang sama pada tahun 1998 di wilayah Bali bagian utara. Selisihnya mencapai kisaran $+100 \mathrm{~mm} \mathrm{~s} / \mathrm{d}+200 \mathrm{~mm}$. Sedangkan untuk wilayah Bali bagian selatan kondisi curah hujan tahun 2016 lebih rendah daripada tahun 1998 dengan selisih mencapai -200 mm. Kemudian untuk bulan Februari, kondisi curah hujan tahun 2016 secara umum lebih tinggi dibandingkan tahun 1998 dengan kisaran selisih $+100 \mathrm{~mm}$ s/d lebih dari +400 $\mathrm{mm} /$ bulan untuk sebagian besar wilayah Bali (Gambar 6c).

Berdasarkan analisis bulanan tersebut, maka dapat diketahui kondisi curah hujan Bali saat EI Nino Kuat 1997/98 dan El Nino Kuat 2015/16 hampir sama pada bulan September dan Oktober yang merupakan masa pertumbuhan El Nino Kuat. Sedangkan pada bulan November, kondisi curah hujan Bali tahun 2015 sedikit lebih kering daripada 1997. Kondisi ini berbarengan dengan kondisi puncak El Nino yang terjadi pada bulan November dengan nilai anomali Nino 3.4 lebih tinggi pada tahun 2015 dibanding 1997. Dengan kata lain, saat puncak El nino (bulan November) kondisi bulan November tahun 2015 sedikit lebih kering daripada November 1997 di Provinsi Bali.

Namun memasuki bulan Desember kondisi curah hujan Bali saat El Nino 2015/16 justru lebih tinggi dibanding El Nino 1997/98 dan berlanjut hingga bulan Februari. Kondisi ini mengindikasikan bahwa fenomena El Nino 2015/16 dalam periode Desember, Januari, Februari 2015/2016 memiliki dampak lebih lemah terhadap pengurangan curah hujan di Provinsi Bali jika dibandingkan dampak yang ditimbulkan El Nino 1997/98 pada periode yang sama. Dengan kata lain, pada fase peluruhan, El Nino 2015/16 tidak memiliki dampak separah dampak yang dihasilkan El Nino 1997/98.

Hasil ini menunjukan bahwa meskipun Oceanic Nino Index antara kedua El Nino cenderung sama namun dampak yang dihasilkan terhadap penurunan curah hujan di Provinsi Bali memiliki perbedaan yang cukup dominan terutama pada 
periode DJF. Dampak penurunan curah hujan pada fase peluruhan El Nino 2015/16 tidak sesignifikan dampak penurunan curah hujan saat fase peluruhan El Nino 1997/98. Hasil ini bersesuaian dengan penelitian sebelumnya [18] terkait perbedaan kondisi dinamika atmosfer-laut yang melatari El Nino 2015/16 dan El Nino 1997/98 terutama pada fase peluruhan (Desember-Maret) sehingga dampak pada curah hujan pada periode tersebut menjadi berbeda.
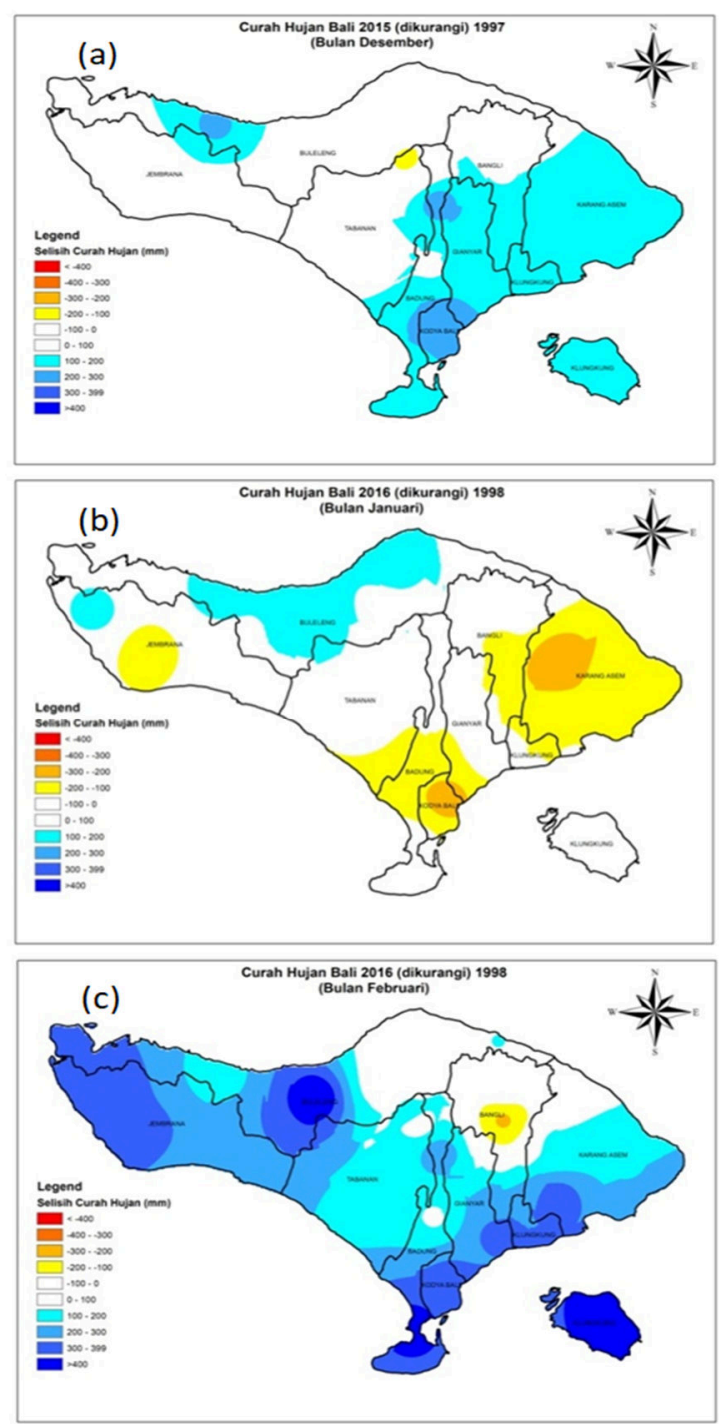

Gambar 6. Perbedaan Curah Hujan Bulanan tahun 2015/2016 (dikurangi) 1997/1998 untuk bulan (a) Desember, (b) Januari, dan (c) Februari

\section{Kesimpulan}

Berdasarkan hasil dan pembahasan yang telah dilakukan maka dapat ditarik kesimpulan bahwa El Nino 2015/16 dan El Nino $1997 / 98$ memiliki pola puncak dan peluruhan yang serupa. Kekuatan indeks El Nino 2015/16 saat kondisi puncak sedikit lebih tinggi dibandingkan El Nino 1997/98. Disamping itu kejadian El Nino 2015/16 memiliki siklus hidup lebih lama daripada El Nino 1997/98 dikarenakan fase awal pertumbuhannya lebih awal sekitar 2 bulan. Namun meskipun demikian, dampak berkurangnya curah hujan bulan SeptemberFebruari di Provinsi Bali saat El Nino Kuat 2015/16 hanya berkisar $-6 \%$ s/d $-46 \%$ tidak separah dampak pengurangan curah hujan yang ditimbulkan El Nino Kuat 1997/98 yang mencapai $-18 \%$ s/d $-72 \%$ dari normalnya. Perbedaan dampak penurunan curah hujan di antara kedua fenomena El Nino ini sangat jelas terlihat saat fase El Nino mulai meluruh (DJF). Kondisi ini dikarenakan adanya perbedaan kondisi evolusi dinamika atmosfer-laut pembentuk kedua fenomena El Nino tersebut. El Nino 1997/98 didominasi oleh dinamika klasik El Nino Pasific Timur (East Pacific El Nino) sedangkan evolusi El Nino 2015/16 menunjukan fenomena campuran antara dinamika El Nino Pasifik Timur dan El Nino Pasifik Tengah (Central Pasifik El Nino) yang mengakibatkan perbedaan dampak terhadap curah hujan terutama pada fase peluruhan El Nino [18]. Dengan demikian, untuk memprakirakan dampak dari El Nino Kuat terhadap curah hujan di Provinsi Bali diperlukan pertimbangan evolusi dinamika atmosfer-laut yang mendasari suatu fenomena El Nino selain berfokus pada tinggi rendahnya indeks EI Nino itu sendiri.

\section{Saran}

Penelitian ini dapat dilanjutkan dengan menambahkan fenomena iklim lain yang terjadi bersamaan dengan fenomena El Nino untuk mendapatkan gambaran yang lebih komprehensif.

\section{Ucapan Terima Kasih}

Penulis mengucapkan terima kasih kepada Tim Observasi dan Analisa Stasiun Klimatologi Klas II Jembrana atas bantuan data dan dukungan yang diberikan. Terima kasih juga kepada National Oceanic and Atmospheric Administration (NOAA) atas data Indeks Nino 3.4 yang disediakan. 


\section{Daftar Pustaka}

[1] Cane, M. A. (2004). The evolution of El Niño, past and future. Earth and Planetary Science Letters, 164,1-10.

[2] Halpert, M. S., and Ropelewski, C. J. (1992). Surface temperature patterns associated with the Southern Oscillation. J. Climate, 5, 577-593.

[3] Bell, G.D., and Halpert, M.S. (1998). Climate assessment for 1997. Bulletin of the American Meteorological Society, 79 (5). S1-S49

[4] Gutman, G., Csiszar, I., dan Romanov, P. (2000). Using NOAA/AVHRR Products to Monitor El Niño Impacts: Focus on Indonesia in 1997-98. Bulletin of the American Meteorological Society, 81 (6). 1189 - 1205.

[5] FAO. (2014, December 7). Understanding the drought impact of El Niño on the global agricultural areas: An assessment using FAO's Agricultural Stress Index (ASI). Roma. Hal. 11. Retrieved from http://www.fao.org/3/a-i4251e.pdf

[6] Bell, G .D. ,Halpert ,M. S., Ropelewski,C.F.,Kousky V.E.,Douglas A.V., Schnell R.C.,dan Gelman, M.E. (1999). Climate Assessment for1998. Bulletin of the American Meteorological Society, 80 (5). S16-S17.

[7] FAO. (2016, December 12). 2015-2016 El Niño Early action and response for agriculture, food security and nutrition. Retrieved from http://www.fao.org/fileadmin/user upload/e mergencies/docs/FAO\%20Early\%20Action $\% 20$ and $\% 20$ Response $\% 2020152016 \% 20$ El\%20Nino\%20Report_Fifth\%20Update\% 200202.pdf

[8] NOAA. (2016, December 12). Understanding El Niño. Retrieved from http://www.noaa.gov/understanding-elnino

[9] Aldrian, E., dan Susanto, R. D. (2003). Identification of three dominant rainfall regions within Indonesia and theirrelationship to sea surface temperature. Intl. J. Climatol, 23, 14351452.
[10] Yuda, I.W.A, dan Prasetia, R. (2014). Analisis Dampak El Nino dan La Nina Terhadap Anomali Curah Hujan di Provinsi Bali Menggunakan Grafik ENSO Impact. Prosiding Seminar Nasional dan Rapat Tahunan Bidang MIPA 2014, 495 503

[11] Climate Prediction Center Internet Team. (2016 December 12). Monthly Atmospheric and SST Indices. Retrieved from https://www.cpc.ncep.noaa.gov/data/indic es/ersst4.nino.mth.81-10.ascii

[12] NOAA. (2016, December 12). Understanding El Niño. Retrieved from http://www.noaa.gov/understanding-elnino

[13] Riduwan. (2 005). Rumus dan Data Dalam Analisis Statistika. Penerbit Alfabeta, Bandung.

[14] Haylock, M., McBride, J. (2001). Spatial Coherence and Predictability of Indonesian Wet Season Rainfall. J. Climate, 14 (18): 3882-3887.

[15] Athoillah, I., Sibarani R.M, Doloksaribu, D.E. (2017). Analisis Spasial Pengaruh Kejadian El Nino Kuat Tahun 2015 dan La Nina Lemah Tahun 2016 Terhadap Kelembaban, Angin, dan Curah Hujan di Indonesia. Jurnal Sains \& Teknologi Modifikasi Cuaca, 18 (1): 33 - 41

[16] Aldrian, E. (2003). Spatial Pattern of ENSO Impact on Indonesia Rainfall. Jurnal Sains \& Teknologi Modifikasi Cuaca, 3 (1): 5-15

[17] Lian, T., Chen, D.K., Tang, Y.M. (2017). Genesis of the 2014-2016 El Niño events. Science China Earth Sciences, 60: 15891600, doi: 10.1007/s11430-016-8315-5

[18] Paek, H., Yu J.-Y., dan Qian, C. (2017). Why were the $2015 / 2016$ and $1997 / 1998$ extreme El Niños different? Geophys. Res. Lett. 44, 1848-1856. doi:10.1002/2016GL071515 